\title{
Exhaled NO and plasma cGMP increase after endotoxin infusion in healthy volunteers
}

\author{
A. Soop*, A. Sollevi*, E. Weitzberg\#, J.O.N. Lundbergף, J. Palm, J. Albert ${ }^{+}$
}

Exhaled NO and plasma cGMP increase after endotoxin infusion in healthy volunteers. A. Soop, A. Sollevi, E. Weitzberg, J.O.N. Lundberg, J. Palm, J. Albert. (C)RS Journals Ltd 2003.

ABSTRACT: Nitric oxide (NO) is believed to be involved in the pathophysiology of sepsis. This study evaluated the activity of the NO pathway in a human endotoxin model.

At baseline and after endotoxin, on-line measurements of exhaled NO (eNO) were made using a chemiluminescence technique with a single-breath method. NO-free air was inhaled prior to exhalation against a resistance. NO in orally and nasally exhaled air and in rectal gas was investigated. Plasma nitrite, nitrate, and guanosine $3^{\prime}, 5^{\prime}$ monophosphate (cGMP) and the events after diclophenac administration were also studied.

Endotoxin infusion resulted in tachycardia and fever. An early increase in oral eNO concentration was observed and oral eNO decreased after diclophenac administration. NO exhaled nasally, NO in rectum gas and nitrite/nitrate levels remained unchanged over the study period. cGMP increased after $4 \mathrm{~h}$.

These findings suggest an early increase in nitric oxide production from the lungs, probably due to increased activity of the constitutive nitric oxide synthase upon endotoxin stimulation. In contrast, nitric oxide production in the upper airways, measured as nasally exhaled nitric oxide and nitric oxide in rectal gas, remained unchanged. Further studies will elucidate if exhaled nitric oxide is a valuable marker of sepsis-induced lung injury and if monitoring of treatment is possible.

Eur Respir J 2003; 21: 594-599.
*Dept of Anaesthesiology and Intensive Care, Center for Surgical Sciences, Huddinge University Hospital, "Dept of Physiology and Pharmacology and \#Dept of Surgical Sciences, Section of Anaesthesiology and Intensive Care, Karolinska Hospital, and ${ }^{+}$Dept of Anaesthesiology and Intensive Care, Danderyd Hospital, Karolinska Institutet, Stockholm, Sweden.

Correspondence: A. Soop, K32 Dept of Anaesthesiology and Intensive Care, Huddinge University Hospital, 14186 Stockholm, Sweden. Fax: 4687795424

E-mail: anne.soop@anaesth.hs.sll.se

Keywords: Endotoxin, exhaled, gut, human, nitric oxide, shock

Received: March 272002

Accepted after revision: October 222002

This study was supported by grants to A Sollevi from the Swedish Medical Research Council, project numbers 7485 and project number 12586, and to E. Weitzberg from the Swedish Heart Lung Foundation.
Sepsis and the systemic inflammatory response syndrome, with subsequent multiple organ failure, are often the major causes of mortality among severely ill patients in intensive care units. The pathophysiology of sepsis involves activation of vascular endothelium and leukocytes, which results in synthesis and release of various mediators, e.g. cytokines, nitric oxide (NO), endothelin and reactive oxygen species [1]. As a local marker of inflammation, $\mathrm{NO}$ gas can be used and measured noninvasively. NO production from the respiratory tract, gut and urinary bladder has been shown to reflect inflammation in these organs [2-4]. In addition, it has recently been shown that exhaled NO (eNO) from the lungs increases in mechanically ventilated patients with pneumonia [5].

Endogenous NO is continuously produced in small amounts as a natural vasodilator by endothelial cells. Epithelial cells in lungs and gut, for example, also produce NO. The vasorelaxing effect of NO is mediated through the activation of the enzyme guanate cyclase, which leads to production of guanosine $3^{\prime}$, 5'-monophosphate (cGMP).

The production of NO from various cells is difficult to measure in vivo, due to the short half-life of NO. Therefore, nitrite/nitrate (more stable oxidation products of $\mathrm{NO}$ ) or cGMP in plasma are often measured as markers of NO production. In most biological fluids NO is rapidly scavenged, whereas it remains remarkably stable in the gaseous phase. This has allowed the development of novel techniques to measure NO in the airways and the gastrointestinal tract by analysing the NO content in exhaled air (fractional exhaled nitric oxide (FENO)) or in gas from the gastro-intestinal lumen.

$\mathrm{NO}$ is produced by specific enzymes, NO synthases (NOSs)
[6], in low (picomolar) concentrations by constitutive NOSs (cNOSs and eNOSs, type-1 and type-3 NOSs). In addition, after inflammatory stimulus, cells such as macrophages produce NO in high amounts [7] via the expression of the inducible NOS (iNOS, type-2 NOS), a process reported to take 6-12 h [8]. Such high concentrations of NO are some of the mediators causing the severe vasodilation that result in hypotension and septic shock [9]. In addition, iNOS has been shown to be expressed in particular tissues, e.g. the hepatic epithelium and in the epithelium of the paranasal sinus [10].

Increased levels of eNO have been observed in various animals, such as dogs and pigs [11, 12] and, in one study, healthy human volunteers subjected to endotoxaemia [13]. In the septic pig, NO release from the gut is unchanged [14] or even reduced [15].

The purpose of this study was to investigate if endotoxin infusion in humans would increase NO levels in the upper and lower airways and in the gut. Nitrite/nitrate and cGMP in plasma were also analysed. Healthy volunteers were exposed to $4 \mathrm{ng} \cdot \mathrm{kg}^{-1}$ Escherichia coli endotoxin, a dose that induces a prominent inflammatory response without being hazardous to the subject [16].

\section{Materials and methods}

\section{Study design}

Eleven males (age 21-43, mean 29.5 yrs) with good health, as confirmed by history, physical examination, electrocardiogram 
and haematological screening, participated in the study. None had taken any medication during the 2 months preceding the study. Approval was given by the Ethics Committee of the Huddinge University Hospital, Karolinska Institutet (Stockholm, Sweden) and all subjects gave their informed consent before participating. The subjects were admitted to the Intensive Care Unit at Huddinge University Hospital (Stockholm, Sweden) $2 \mathrm{~h}$ after a light breakfast. Intravenous and radial artery catheters were inserted. Electrocardiogram was performed constantly and body temperature was measured by ear thermometer. A 30-min rest period followed the placement of catheters, and thereafter, baseline blood samples were collected from the radial artery catheter and endotoxin was administered intravenously. Blood samples for nitrite/nitrate were collected at baseline, 4 and $6 \mathrm{~h}$ and for cGMP at baseline and $4 \mathrm{~h}$. After $4 \mathrm{~h}$ the subjects received $50 \mathrm{mg}$ diclophenac rectally and after $6 \mathrm{~h}$ the experiment was terminated. Blood pressure, heart rate and temperature were registered hourly. Measurements of FENO and NO in rectal gas and sampling for blood gas content and haemoglobin were performed every hour.

Four healthy male volunteers (age 22-23, mean 22.5 yrs) also without medication for 2 months, served as controls for eNO and possible effects of time and supine position. Four healthy subjects (two males and two females, age 37-46, mean 43.2 yrs) served as controls for hyperventilation and oral eNO. These subjects had their end-tidal carbon dioxide $\left(\mathrm{CO}_{2}\right)$ measured (Datex end-tidal $\mathrm{CO}_{2}$ monitor; Datex-Ohmeda, Helsinki, Finland). Initially, eNO was measured at rest and then at hyperventilation until side-effects appeared (i.e. $5 \mathrm{~min}$, then NO measuring, then repeated hyperventilation and another NO measuring). After recovery, with normocapnia, the last NO measurement was performed. The control subjects did not receive an artery catheter, endotoxin or diclophenac, or any rectal catheter for measuring NO.

\section{Measurements of nitric oxide in exhaled air}

On-line measurements of NO levels were made using a chemiluminescence technique according to the recommendations described for measurement of eNO in the European Respiratory Society Task Force Report using a single-breath method [17]. Compressed NO-free air was continuously introduced into a nondiffusing gas collection bag (Hans Rudolph Inc., Kansas City, KS, USA) at a rate of 2-3 $\mathrm{L} \cdot \mathrm{min}^{-1}$. The bag was connected via an antiviral filter to a three-way non-rebreathing valve (Hans Rudolph Inc.), which in turn was connected to another antiviral filter. This filter was either directly used as a mouthpiece or was connected to a nose mask. The subject was asked to inhale NO-free air via the nose or mouth and immediately exhale via the same route at a flow of $0.10 \pm 0.02 \mathrm{~L} \cdot \mathrm{s}^{-1}$ against a resistance of $100 \mathrm{~cm} \cdot \mathrm{H}_{2} \mathrm{O} \cdot \mathrm{L} \cdot \mathrm{s}^{-1}$ for a period of $15 \mathrm{~s}$. The exhaled air passed through a linear pneumotachymeter (Hans Rudolph Inc.) after which the resistor (Hans Rudolph Inc.) was connected. Exhaled air was continuously sampled into the NO analyser (77 AM; Eco Physics, Dürnten, Switzerland). The signal outputs from these devices were connected to a computer-based system (Exhaled Breath Analyser; Aerocrine $\mathrm{AB}$, Stockholm, Sweden), yielding an instant on-screen display of flow for biofeedback. NO concentration (FENO) (parts per billion $(\mathrm{ppb})=\mathrm{nl} \cdot \mathrm{L}^{-1}$ ) and NO output were calculated using the equation:

$$
\begin{gathered}
V^{\prime} \mathrm{NO}=[\mathrm{NO}] \times \text { airflow rate } \\
\left(\mathrm{nl} \cdot \mathrm{min}^{-1}=\mathrm{nl} \cdot \mathrm{L}^{-1} \times \mathrm{L} \cdot \mathrm{s}^{-1} \times 60^{-1}\right)
\end{gathered}
$$

where $V^{\prime} \mathrm{NO}$ is the amount of NO exhaled per unit time.
The NO concentration FENO showed a stable plateau after an initial peak in all measurements. eNO through the mouth was measured while exhaling through a mouthpiece and eNO through the nose was measured, with a closed mouth, through a nose mask. Nasal values are presented as nasal values minus mouth values, according to a method described by PALM et al. [18]. All exhaled measurements were made in duplicate and each data point represents the average of both measurements. The detection limit for NO was $1 \mathrm{ppb}$.

\section{Measurements of rectal nitric oxide}

Rectal NO was measured using the technique described by Herulf et al. [19]. An all-silicon catheter (Argyle, No 14; Sherwood Medical, Tullamore, Ireland) equipped with an inflatable balloon was inserted $10-12 \mathrm{~cm}$ into the rectum by the volunteers themselves. Lubricating gel free from local anaesthetic was used. The balloon was then inflated with NOfree air and incubated in the rectum for $10 \mathrm{~min}$, allowing NO to diffuse into the balloon. The sample was aspirated and analysed immediately by a chemiluminescence NO analyser (AM 77; Eco Physics). The peak NO concentration was registered. The detection limit for NO was $1 \mathrm{ppb}$.

\section{Endotoxin administration}

The lipopolysaccharide used was National Reference Endotoxin, E. coli (Lot G 1; United States Pharmacopeial Convention Inc., Rockville, MD, USA). The endotoxin was given at a dose of $4 \mathrm{ng} \cdot \mathrm{kg}^{-1}$, made in $0.9 \%$ saline solution $\left(1 \mathrm{~mL} \cdot \mathrm{kg}^{-1}\right)$ and administered intravenously over $5 \mathrm{~min}$, followed by a flush of $20 \mathrm{~mL}$ saline.

\section{Nitrite, nitrate and cGMP in plasma}

Nitrite and nitrate concentrations in plasma were analysed with a fluorometric nitrite/nitrate assay kit (Cayman Chemical, Ann Arbor, MI, USA) according to the manufacturers' instructions. cGMP was assayed in plasma after ethanol extraction using a cGMP radioimmunoassay kit (Amersham Biosciences, Uppsala, Sweden) according to the manufacturers' instructions (sensitivity $0.006 \mathrm{nmol} \cdot \mathrm{L}^{-1}$, range $0.02-$ $1.3 \mathrm{nmol} \cdot \mathrm{L}^{-1}$ ). Blood for analysing nitrite, nitrate and cGMP was collected with a Vacutainer ${ }^{\mathrm{TM}}$ (Becton-Dickinson Vacutainer Systems Europe, Plymouth, UK) in $5 \mathrm{~mL}$ standard ethylenediamine tetraacetic acid tubes.

\section{Haemoglobin and arterial carbon dioxide tension}

Blood gas samples were analysed with a Rapidlab 855

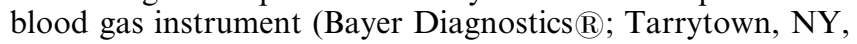
USA) and haemoglobin was analysed using an Advia 120

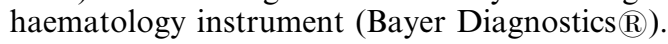

\section{Statistics}

Descriptive statistics are presented as mean \pm SEM. Statistical analysis was performed using single-factor repeated measures used for evaluation by Friedman's analysis of variance. For cGMP, a paired t-test was used. 


\section{Results}

\section{Physiological variables}

All volunteers that entered also completed the study. There were no unexpected side-effects. Systolic blood pressure increased significantly $(\mathrm{p}<0.001)$ and diastolic blood pressure decreased significantly $(\mathrm{p}<0.001)$ after $2 \mathrm{~h}$. Heart rate and body temperature increased significantly $(\mathrm{p}<0.001)$. The carbon dioxide tension $\left(\mathrm{Pa}_{\mathrm{a}}, \mathrm{CO}_{2}\right)$ decreased after $2 \mathrm{~h}$ and remained unchanged throughout the study period. Haemoglobin decreased from the fourth to sixth hour (table 1).

\section{Nitric oxide in exhaled air and from the rectal catheter}

Oral eNO, VNO, increased in all 11 subjects (fig. 1a). Mean values increased by $33 \% \quad(\mathrm{p}<0.001)$ from baseline, $24 \pm$ $5 \mathrm{~nL} \cdot \mathrm{min}^{-1}$ to $32 \pm 4 \mathrm{~nL} \cdot \mathrm{min}^{-1}$, after $2 \mathrm{~h}$ and then reached a plateau. Oral VNO showed a significant $(\mathrm{p}<0.05)$ decrease back to baseline values observed 1 and $2 \mathrm{~h}$ after diclophenac administration.

Nasal eNO did not change during the course of the experiment $(\mathrm{p}=0.52)$. Baseline values were $127 \pm 18 \mathrm{~nL} \cdot \mathrm{min}^{-1}$ and $135 \pm 17 \mathrm{~nL} \cdot \mathrm{min}^{-1}$ at $4 \mathrm{~h}$. Nasal eNO did not decrease after diclophenac administration $(\mathrm{p}=0.06)$ and at $6 \mathrm{~h}$ was $109 \pm 14 \mathrm{~nL} \cdot \mathrm{min}^{-1}$ (fig. 1b). The control group showed no statistical change over the study period in oral eNO or nasal eNO. Oral eNO was $28.9 \pm 5.2 \mathrm{~nL} \cdot \mathrm{min}^{-1}$ at baseline and $30.5 \pm 4.1 \mathrm{~nL} \cdot \mathrm{min}^{-1}$ at $4 \mathrm{~h}$. Nasal VNO was $72 \pm 8 \mathrm{~nL} \cdot \mathrm{min}^{-1}$ at baseline and $95 \pm 26 \mathrm{~nL} \cdot \mathrm{min}^{-1}$ at $4 \mathrm{~h}$. The controls regarding hyperventilation had at-rest end-tidal $\mathrm{CO}_{2}$ of $5.0 \pm 0.28 \mathrm{kPa}$, then $2.5 \pm 0.13 \mathrm{kPa}$ after the first period of hyperventilation, $2.3 \pm 0.12 \mathrm{kPa}$ after the second and $4.8 \pm 0.35 \mathrm{kPa}$ after recovery. Oral eNO values were $33 \pm 10 \mathrm{~nL} \cdot \mathrm{min}^{-1}, 28 \pm$ $8 \mathrm{~nL} \cdot \mathrm{min}^{-1}, 32 \pm 10 \mathrm{~nL} \cdot \mathrm{min}^{-1}$ and $31 \pm 10 \mathrm{~nL} \cdot \mathrm{min}^{-1}$, respectively. Basal levels of rectal NO were $59 \pm 11 \mathrm{ppb}$, then $58 \pm 18 \mathrm{ppb}$ at $4 \mathrm{~h}$ and $91 \pm 26 \mathrm{ppb}$ at $6 \mathrm{~h}$, and did not show any significant difference $(\mathrm{p}=0.46)$ over the study period (fig. 1c).

\section{cGMP, nitrite and nitrate}

cGMP increased in all 11 subjects, from $3.46 \pm 0.19 \mathrm{nmol} \cdot \mathrm{L}^{-1}$ at baseline to $5.06 \pm 0.35 \mathrm{nmol} \cdot \mathrm{L}^{-1} 4 \mathrm{~h}$ after endotoxin $(\mathrm{p}=0.02$, fig. 2a). Nitrite and nitrate levels in plasma were not significantly changed over the study period (fig. 2b). Nitrite baseline levels were $1.57 \pm 0.31 \mu \mathrm{mol} \cdot \mathrm{L}^{-1}, 1.03 \pm 0.20 \mu \mathrm{mol} \cdot \mathrm{L}^{-1}$ after $4 \mathrm{~h}$ and $1.8 \pm 0.36 \mu \mathrm{mol} \cdot \mathrm{L}^{-1}$ at $6 \mathrm{~h}$. Nitrate baseline levels were $50.1 \pm 8.1 \mu \mathrm{mol} \cdot \mathrm{L}^{-1}, 50.8 \pm 12.0 \mu \mathrm{mol} \cdot \mathrm{L}^{-1}$ after $4 \mathrm{~h}$ and $49.6 \pm 9.9 \mu \mathrm{mol} \cdot \mathrm{L}^{-1}$ at $6 \mathrm{~h}$.

\section{Discussion}

The primary finding of this study was that oral eNO increased upon endotoxin administration, indicating enhanced production of $\mathrm{NO}$ from the lower airways. Nasal eNO was not significantly changed by endotoxin. Further, plasma cGMP increased $4 \mathrm{~h}$ after endotoxin compared to baseline levels, whereas nitrite/nitrate in plasma was unchanged. Increased heart rate, fever and blood pressure response indicate that the volunteers responded to the endotoxin.

eNO has been extensively studied, mainly in patients with asthma showing increased levels corresponding well with the grade of inflammation and anti-inflammatory treatment with steroids [2]. Further, NO in exhaled air has been shown to increase early after endotoxin challenge in animal models [11].

In a study by VANDIVIER et al. [13], eNO increased $\sim 3 \mathrm{~h}$ after endotoxin infusion in healthy volunteers, which is in accordance with the findings of this study. VANDIVIER et al. [13] performed measurements with a noseclip and without exhalation against an expiratory resistance. Such an approach would greatly increase the risk of contamination with nasal NO to orally exhaled levels [20]. In the present study, the highly standardised method for eNO recommended by the European Respiratory Society and the American Thoracic Society was used $[17,21]$. This includes exhalation against a resistance at a fixed flow rate and allows for good separation of lower airway NO from nasal NO. It is therefore very likely that the increased oral NO observed in the current study derives from the lower airways or the lungs. This study found a decrease in $\mathrm{Pa}, \mathrm{CO}_{2}$, indicating hyperventilation. However, this decrease lasted throughout the study period, while the levels of eNO started decreasing and returned to near baseline values after $6 \mathrm{~h}$. Hence, the authors suggest that there is no connection between the decrease in $\mathrm{Pa}, \mathrm{CO}_{2}$ and the increase in eNO. It appears that the levels of eNO are not due to hyperventilation per se, provided the measurements are performed using a constant flow. It is important to stress that during flow-controlled single-breath exhalations hyperventilation should not influence eNO. To the authors' knowledge there are no such studies in the literature. However, it could be argued that the decrease in oral eNO observed from $4-6 \mathrm{~h}$ is connected to the decrease in hyperventilation expected when the $\mathrm{CO}_{2}$ production decreases in parallel with fever reduction. In the four control subjects, no indication of correlation between hyperventilation and oral eNO was found. The early increase in NO production after endotoxin seen in this study, within $2 \mathrm{~h}$ after triggering the inflammatory reaction, indicates that there is an augmented activity of cNOS in the lungs rather than an upregulation of iNOS expression, since iNOS induction upon endotoxin and/or cytokines, in the experimental setting, is known to take $\geqslant 6-12 \mathrm{~h}$ [8]. These findings are in line with previous studies in animal endotoxin models. Hussain et al. [12] found

Table 1.-Body temperature, haemodynamic parameters, arterial carbon dioxide tension $\left(P a, \mathrm{CO}_{2}\right)$ and haemoglobin at baseline and after endotoxin infusion

\begin{tabular}{|c|c|c|c|c|c|c|c|}
\hline & Baseline & $1 \mathrm{~h}$ & $2 \mathrm{~h}$ & $3 \mathrm{~h}$ & $4 \mathrm{~h}$ & $5 \mathrm{~h}$ & $6 \mathrm{~h}$ \\
\hline Temp. & $36.8 \pm 0.1$ & $37.1 \pm 0.3$ & $38.1 \pm 0.2^{\mathrm{B}, 1^{* *}} 3,4^{*}$ & $38.9 \pm 0.3^{\mathrm{B}, 1,6^{* *} 2^{*}}$ & $39.1 \pm 0.2^{\mathrm{B}, 1,6^{* *} 2^{*}}$ & $38.5 \pm 0.2^{1,2^{* *}}$ & $37.9 \pm 0.1^{\mathrm{B}, 3,4^{* *} 1^{*}}$ \\
\hline HR & $65 \pm 4$ & $81 \pm 5^{3-5^{* *} B^{*}}$ & $93 \pm 5^{\mathrm{B}^{* *} 3^{*}}$ & $107 \pm 4^{\mathrm{B},} 1^{* *} 2,7^{*}$ & $104 \pm 4^{\mathrm{B},} 1^{* *}$ & $99 \pm 3$ B, $1^{* *}$ & $93 \pm 1 \mathrm{~B}^{* * 3 *}$ \\
\hline SBP & $130 \pm 5$ & $154 \pm 7^{6 * *} \mathrm{~B}, 5^{*}$ & $149 \pm 5^{1 *}$ & $141 \pm 7^{6 *}$ & $132 \pm 5$ & $123 \pm 4 \quad 1,2^{* *}$ & $116 \pm 3^{1,2^{* *}}$ \\
\hline DBP & $70 \pm 2$ & $75 \pm 4^{2-6^{*}}$ & $62 \pm 2^{1 *}$ & $62 \pm 3^{1 *}$ & $63 \pm 4^{1 *}$ & $61 \pm 3^{1 *}$ & $62 \pm 3^{1 *}$ \\
\hline $\mathrm{Pa}, \mathrm{CO}_{2}$ & $5.7 \pm 0.12$ & $5.1 \pm 0.1$ & $4.7 \pm 0.3^{\mathrm{B}^{*}}$ & $4.3 \pm 0.3^{\mathrm{B}^{* *}}$ & $4.6 \pm 0.2^{\mathrm{B}^{*}}$ & $4.6 \pm 0.1^{\mathrm{B}^{*}}$ & $4.6 \pm 0.1^{\mathrm{B}^{*}}$ \\
\hline $\mathrm{Hb}$ & $143 \pm 3$ & $143 \pm 3^{4-6 * *}$ & $142 \pm 3^{4,5^{* *}} 6^{*}$ & $140 \pm 3^{5^{*}}$ & $137 \pm 2^{\mathrm{B}, 1^{* *} 2^{*}}$ & $136 \pm 2^{\mathrm{B}, 1^{* *}} 3^{*}$ & $138 \pm 2^{\mathrm{B}, 1^{* *} 2^{*}}$ \\
\hline
\end{tabular}

Data are presented as mean \pm SEM. Diclophenac was administered after $4 \mathrm{~h}$. Temp.: body temperature $\left({ }^{\circ} \mathrm{C}\right)$; HR: heart rate $\left(\right.$ beats $\left.\times \mathrm{min}^{-1}\right)$; SBP: systolic blood pressure $(\mathrm{mmHg})$; DBP: diastolic blood pressure $(\mathrm{mmHg}) ; \mathrm{Hb}$ : haemoglobin $\left(\mathrm{g} \times \mathrm{L}^{-1}\right)$. B: baseline; 1-6: statistical significance between the various hours of the experiment; *: $p<0.05 ; * *: p<0.001$. 

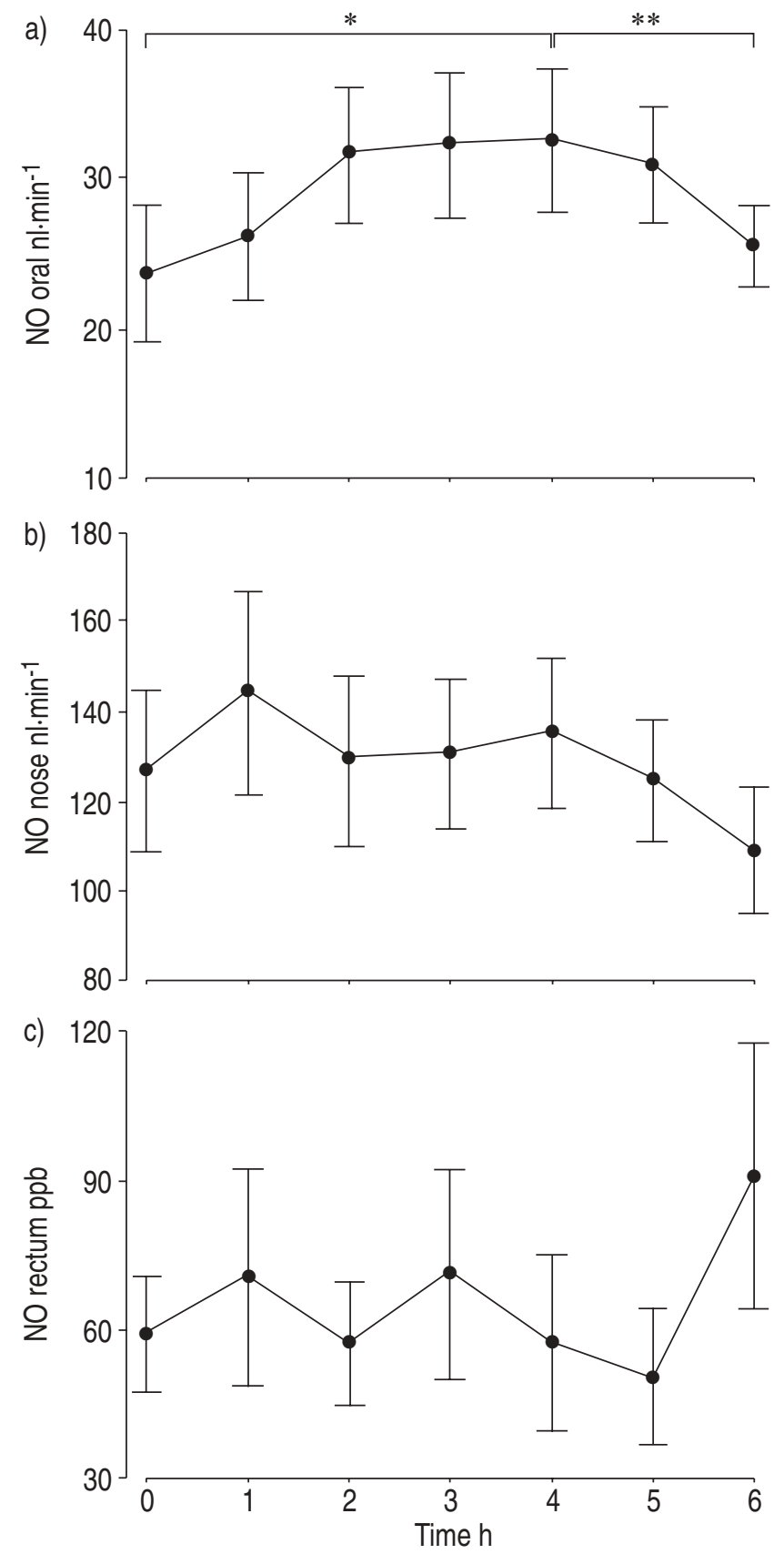

Fig. 1. - Nitric oxide (NO) concentrations in a) orally and b) nasally exhaled air. c) NO concentration measured from the rectum. Measurements were performed before and every hour, during the $6 \mathrm{~h}$ after endotoxin infusion. Diclophenac (50 mg rectally) was administered after $4 \mathrm{~h}$. NO exhaled nasally and NO in rectum gas did not change significantly over the study period. Each value indicates mean \pm SEM. $*:$ p $<0.001 ; * *: p<0.05$.

elevated levels of eNO in endotoxic dogs within $30 \mathrm{~min}$, while there was no evidence of iNOS induction. The increase in eNO after endotoxin in rats can be blocked by NOS inhibitors, such as $N$-nitro-L-arginine methyl ester [22]. Taken together, these data suggest increased activity of cNOS in the lower airways and lungs, which of course does not exclude iNOS derived eNO in the later phases of the systemic inflammatory response.

Previous studies have suggested that oral eNO represents NO from the lower airways [23]. However, it has been shown that oral NO production exists and is dependent on intake of
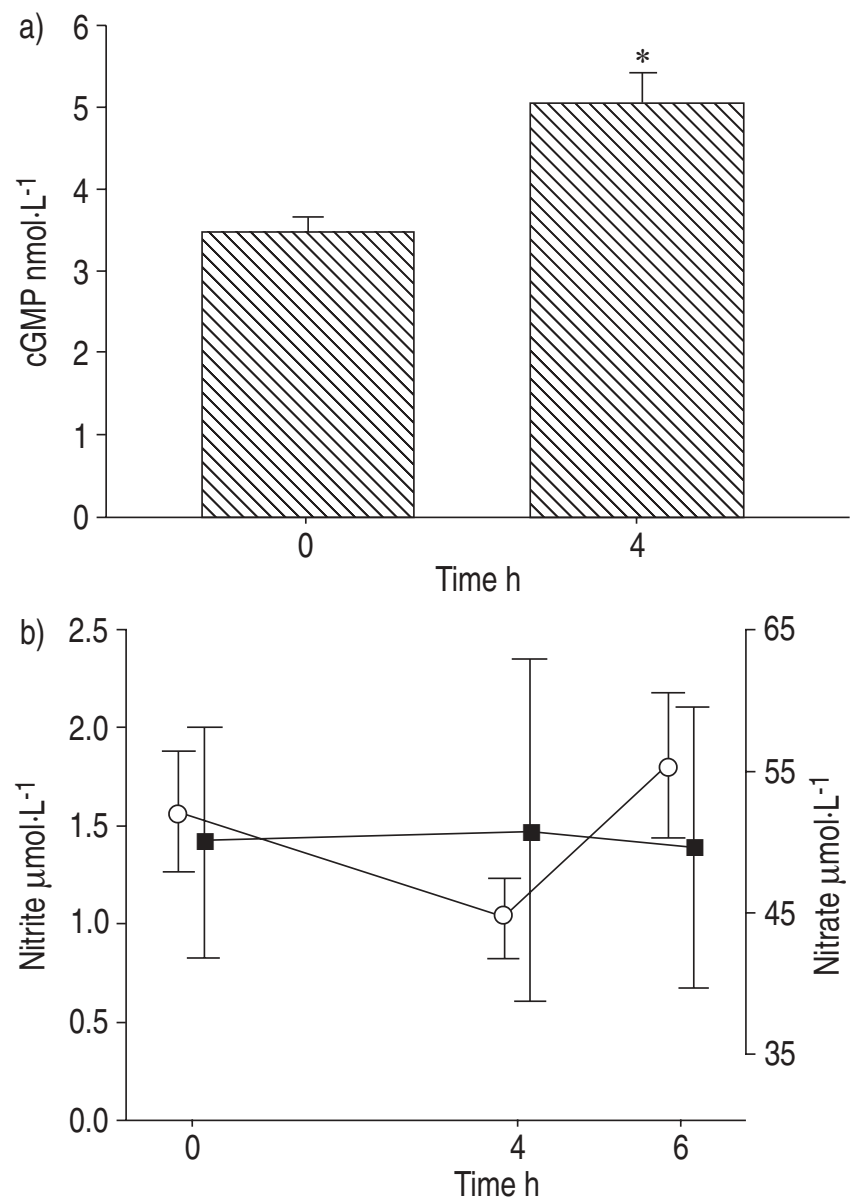

Fig. 2.-a) Cyclic guanosine monophosphate (cGMP) in plasma before and $4 \mathrm{~h}$ after endotoxin. b) Mean \pm SEM plasma levels of nitrite $(\bigcirc)$ and nitrate $(\mathbf{a})$ before and 4 and $6 \mathrm{~h}$ after endotoxin challenge, there was no significant change over the study period. Diclophenac (50 $\mathrm{mg}$ rectally) was administered after $4 \mathrm{~h} .{ }^{*}: \mathrm{p}=0.02$.

nitrate, which is reduced to nitrite and further to NO by bacteria in the oral cavity [24]. Recently, the authors observed that the oral cavity and oropharynx contributes to approximately half of the NO levels in orally exhaled air, shown by measuring NO production from tracheotomised patients [25]. The authors therefore cannot disregard the fact that the increase in oral eNO after endotoxin challenge derives from NO produced in the mouth. However, the volunteers 2-h fast in the current study is a contradicting factor. In addition, plasma levels of nitrite and nitrate remained stable, which argues against an increased secretion of nitrate into the oral cavity. Therefore, the authors hypothesise that the increase in orally exhaled levels of NO measured in the current study is a sign of inflammatory response and reflects a change in NO production in the lower airways. It is known that endotoxin challenge to human volunteers increases cardiac output but does not influence mean pulmonary artery pressure during the first $3 \mathrm{~h}$ [26]. The possible effects of alterations in the pulmonary blood flow on eNO have previously been investigated in humans. Changing pulmonary blood flow had no effect on this mechanism [27]. An increase in pulmonary blood flow would allow haemoglobin to bind more NO per time unit, which, theoretically, could result in a decrease in eNO.

No significant change in nasal NO production upon endotoxin challenge was found. The method of subtracting the orally from the nasally exhaled levels was used [18]. This method is proposed to reflect upper airway NO production 
although several other methods have been suggested [21]. The amount of NO exhaled from the nose is approximately five times higher compared to NO exhaled from the mouth. The authors speculate that such a relatively small amount of increase as seen in the orally measured NO would easily be blunted by the background NO in the nose.

The decrease in NO production from the lungs after diclophenac administration shown in the current study is in accordance with previous findings where a cyclo-oxygenase inhibitor (ibuprofen) decreased alveolar NO flow rates [13]. These findings give further strength to the possibility that a nonsteroid anti-inflammatory drug (NSAID) inhibits the activity of eNOS or iNOS or both, as previously shown in in vitro studies [28] and in pigs [29]. With the present study design, it was not possible to draw any conclusions of the effect of diclophenac on NO production. However, it could be speculated that there is NOS expressed in the lungs, with a decreased activity regulated by NSAID.

There was no change in NO levels from the gut after endotoxin challenge or after diclophenac administration. In local inflammatory diseases, NO from the gut lumen is markedly increased [30]. In porcine inflammatory models, NO release from the gut is unchanged [14] or even reduced [15]. The difference in results might be due to the difference in local versus systemic inflammation or, as previously mentioned, the time for the expression of iNOS. Species-specific conditions may also play a role. The dose of endotoxin should be considered, as in pigs it can reach $20 \mu \mathrm{g} \cdot \mathrm{kg}^{-1} \cdot \mathrm{h}^{-1}$ compared to human volunteers who receive $4 \mathrm{ng} \cdot \mathrm{kg}^{-1}$ once.

The increase in plasma cGMP $4 \mathrm{~h}$ after endotoxin is contrary to that reported by VANDIVIER et al. [13], where both urinary and plasma levels of cGMP were unaltered by endotoxin and by endotoxin combined with an NO donor. The current study used a radioimmunoassay, whilst VANDIVIER et al. [13] used an enzyme immunoassay method to analyse cGMP. Both are well known, widely used methods and, according to the manufacturer, comparable. It is not apparent why different results are obtained. However, the current study used different lots of $E$. coli, which might have implication [16]. In septic patients, plasma cGMP increases [31] and, in volunteers, NO inhalation increases plasma cGMP in a dose-dependent manner [32]. Further studies to assess the effect of endotoxin challenge on cGMP seem warranted.

As in the study by VANDIVIER et al. [13], nitrite/nitrate levels in plasma remained unchanged after endotoxin challenge. This is contrary to previous in vitro findings [33] as well as findings from studies in patients with septicaemia [34]. Other authors have stated that the plasma nitrite/ nitrate levels may not always reflect NO production [35]. In addition, the authors have previously found that nitrite/ nitrate levels remain unchanged $1-4 \mathrm{~h}$ after endotoxin challenge in healthy volunteers (A. Soop, unpublished results). However, VANDIVIER et al. [13] found elevated urinary levels of nitrite/nitrate in the late follow-up time, which might reflect an activation of iNOS.

In summary, this study found enhanced nitric oxide production from the lungs after endotoxin challenge in healthy human volunteers. Advantages of measuring nitric oxide in exhaled air are that the method is noninvasive and provides immediate and continuous results. Further studies will reveal whether this method has a place in the intensive care unit monitoring arsenal to measure inflammatory response during sepsis.

Acknowledgements. The authors would like to thank I. Hellström and C. Nihlén for skilful technical assistance.

\section{References}

1. Murphy K, Haudek SB, Thompson M, Giroir BP. Molecular biology of septic shock. New Horiz 1998; 6: 181-193.

2. Alving K, Weitzberg E, Lundberg JM. Increased amount of nitric oxide in exhaled air of asthmatics. Eur Respir J 1993; 6: $1368-1370$.

3. Herulf M, Svenungsson B, Lagergren A, et al. Increased nitric oxide in infective gastroenteritis. J Infect Dis 1999; 180: $542-545$.

4. Lundberg JO, Weitzberg E, Lundberg JM, Alving K. Intragastric nitric oxide production in humans: measurements in expelled air. Gut 1994; 35: 1543-1546.

5. Adrie C, Monchi M, Dinh-Xuan AT, Dall'Ava-Santucci J, Dhainaut JF, Pinsky MR. Exhaled and nasal nitric oxide as a marker of pneumonia in ventilated patients. Am J Respir Crit Care Med 2001; 163: 1143-1149.

6. Palmer RM, Ashton DS, Moncada S. Vascular endothelial cells synthesize nitric oxide from L-arginine. Nature 1988; 333: 664-666.

7. Radomski MW, Palmer RM, Moncada S. Glucocorticoids inhibit the expression of an inducible, but not the constitutive, nitric oxide synthase in vascular endothelial cells. Proc Natl Acad Sci USA 1990; 87: 10043-10047.

8. Palmer RM, Bridge L, Foxwell NA, Moncada S. The role of nitric oxide in endothelial cell damage and its inhibition by glucocorticoids. Br J Pharmacol 1992; 105: 11-12.

9. Goode HF, Howdle PD, Walker BE, Webster NR. Nitric oxide synthase activity is increased in patients with sepsis syndrome. Clin Sci (Colch) 1995; 88: 131-133.

10. Lundberg JO, Farkas-Szallasi T, Weitzberg E, et al. High nitric oxide production in human paranasal sinuses. Nat Med 1995; 1: 370-373.

11. Fujii Y, Goldberg P, Hussain SN. Intrathoracic and extrathoracic sources of exhaled nitric oxide in porcine endotoxemic shock. Chest 1998; 114: 569-576.

12. Hussain SN, Abdul-Hussain MN, el-Dwairi Q. Exhaled nitric oxide as a marker for serum nitric oxide concentration in acute endotoxemia. J Crit Care 1996; 11: 167-175.

13. Vandivier RW, Eidsath A, Banks SM, et al. Downregulation of nitric oxide production by ibuprofen in human volunteers. J Pharmacol Exp Ther 1999; 289: 13981403.

14. Snygg J, Aneman A, Pettersson A, Fandriks L. Jejunal mucosal nitric oxide production and substrate dependency during acute mesenteric hypoperfusion in pigs. Crit Care Med 2000; 28: 2563-2566.

15. Malmström RE, Björne H, Oldner A, et al. Intestinal nitric oxide in the normal and endotoxemic pig. Shock 2002; 18 : 456-460.

16. Suffredini AF, Hochstein HD, McMahon FG. Dose-related inflammatory effects of intravenous endotoxin in humans: evaluation of a new clinical lot of Escherichia coli O: 113 endotoxin. J Infect Dis 1999; 179: 1278-1282.

17. Kharitonov S, Alving K, Barnes PJ. Exhaled and nasal nitric oxide measurements: recommendations. The European Respiratory Society Task Force. Eur Respir J 1997; 10: 1683-1693.

18. Palm JP, Graf P, Lundberg JO, Alving K. Characterization of exhaled nitric oxide: introducing a new reproducible method for nasal nitric oxide measurements. Eur Respir $J$ 2000; 16: 236-241.

19. Herulf M, Ljung T, Hellstrom PM, Weitzberg E, Lundberg JO. Increased luminal nitric oxide in inflammatory bowel disease as shown with a novel minimally invasive method. Scand J Gastroenterol 1998; 33: 164-169.

20. Kimberly B, Nejadnik B, Giraud GD, Holden WE. Nasal contribution to exhaled nitric oxide at rest and during breathholding in humans. Am J Respir Crit Care Med 1996; 153: 829-836.

21. Recommendations for standardized procedures for the on-line and off-line measurement of exhaled lower respiratory nitric oxide and nasal nitric oxide in adults and children-1999. This 
official statement of the American Thoracic Society was adopted by the ATS Board of Directors, July 1999. Am J Respir Crit Care Med 1999; 160: 2104-2117.

22. Aaron SD, Valenza F, Volgyesi G, Mullen JB, Slutsky AS, Stewart TE. Inhibition of exhaled nitric oxide production during sepsis does not prevent lung inflammation. Crit Care Med 1998; 26: 309-314.

23. Dweik RA, Laskowski D, Abu-Soud HM, et al. Nitric oxide synthesis in the lung. Regulation by oxygen through a kinetic mechanism. J Clin Invest 1998; 101: 660-666.

24. Zetterquist W, Pedroletti C, Lundberg JO, Alving K. Salivary contribution to exhaled nitric oxide. Eur Respir $J$ 1999; 13: 327-333.

25. Törnberg DCF, Marteus H, Schedin U, Alving K, Lundberg JON, Weitzberg E. Nasal and oral contribution to inhaled and exhaled nitric oxide: a study in tracheotomized patients. Eur Respir J 2002; 19: 859-864.

26. Suffredini AF, Fromm RE, Parker MM, et al. The cardiovascular response of normal humans to the administration of endotoxin. N Engl J Med 1989; 321: 280-287.

27. Pogliaghi S, Krasney JA, Pendergast DR. Effect of gravity on lung exhaled nitric oxide at rest and during exercise. Respir Physiol 1997; 107: 157-164.

28. Menzel JE, Kolarz G. Modulation of nitric oxide synthase activity by ibuprofen. Inflammation 1997; 21: 451-461.
29. Dahm P, Thorne J, Zoucas E, Martensson L, Myhre E, Blomquist S. Differential effects of nitric oxide synthase modulation on porcine systemic and pulmonary circulation in vivo. Crit Care Med 1997; 25: 280-285.

30. Lundberg JO, Hellstrom PM, Lundberg JM, Alving K. Greatly increased luminal nitric oxide in ulcerative colitis. Lancet 1994; 344: 1673-1674.

31. Schneider F, Lutun P, Couchot A, Bilbault P, Tempe JD. Plasma cyclic guanosine $3^{\prime}-5^{\prime}$ monophosphate concentrations and low vascular resistance in human septic shock. Intensive Care Med 1993; 19: 99-104.

32. Albert J, Wallen NH, Broijersen A, Frostell C, Hjemdahl P. Effects of inhaled nitric oxide compared with aspirin on platelet function in vivo in healthy subjects. Clin Sci (Colch) 1996; 91: 225-231

33. Cendan JC, Moldawer LL, Souba WW, Copeland EM, Lind DS. Endotoxin-induced nitric oxide production in pulmonary artery endothelial cells is regulated by cytokines. Arch Surg 1994; 129: 1296-1300.

34. Endo S, Inada K, Nakae H, et al. Nitrite/nitrate oxide (NOx) and cytokine levels in patients with septic shock. Res Commun Mol Pathol Pharmacol 1996; 91: 347-356.

35. Strand OA, Leone A, Giersky KE, Kirkeboen KA. Nitric oxide indices in human septic shock. Crit Care Med 2000; 28: 2779-2785. 